\title{
Death and dying: A systematic review into approaches used to support bereaved children.
}

\author{
David Duncan \\ University of Strathclyde
}

\begin{abstract}
Background: Supporting, caring for and working with bereaved children is both daunting and challenging, yet not much is known about how schools can help children to cope with death and dying. The main objective of this study was to identify approaches used to support children who are grieving and explore implications for teachers. The use of retrospective autoethnography sets out this review as a practitioner enquiry-based project.
\end{abstract}

Methods: A systematic review of literature involving school-aged children was undertaken. The focus of these studies was on approaches - viewed by children, parents and teachers which helped children cope having recently been bereaved. The studies all relate to children aged 3-18. Four databases were searched up to and including Spring 2019: British Education Index; Child Development \& Adolescent Studies; ERIC; and PsycINFO. The included studies were analysed using a qualitative enquiry model which draws on metaethnography.

Results: Abstracts and titles were examined of seven hundred and sixty-five articles. Following the selection process, 15 studies were included. All of the studies were peerreviewed, published after 2000 and used qualitative methods of data collection (interviews, ethnographies, a case-study and observations). Encouraging children to openly communicate, find comfort in various ways and express emotion regularly were the most common approaches.

Conclusion: The results indicate that if approaches are taken, children can feel supported during a challenging and fearful time in their lives. Future research is required on the effects of specific teacher-led approaches in schools.

Keywords: death, approaches, bereavement, children 


\section{Introduction}

Bereavement can be a very significant and stressful time in a child's life (Auman, 2007; Mallon, 2011). Approximately one child in every school class in Scotland has experienced the death of a parent, brother or sister (Fauth, Thompson and Penny, 2009); Scottish Partnership for Palliative Care, 2018). Learning to live with the void that is left when a loved one dies is a vital part of the grieving process. If we truly want to improve the lives of children and young people, we need to look at the role of education in this and explore what schools can do to support pupils in relation to death, dying and bereavement. The potential impact of death on a child is highly unpredictable and complicated: with possible effects to behaviour and academic performance (Holland, 2008; Schlozman, 2003), nor is it clear to see the impact death is having on a child. That is why, in schools, children are often left to grieve alone: practitioners are in fear of the 'right thing' to do or say (Gunn, 2009). When experiencing loss, children become vulnerable (Graham, 2012). They will struggle to make sense of death as their social, emotional and developmental worlds are turned upside down. Death is a part of life. It affects $100 \%$ of our children. As children spend many of their days at school, teachers have an important role in developing approaches around death and dying.

The term 'approaches' is used in this paper as a way of dealing with child bereavement. It refers to the way grieving is considered in relation to helping children to cope. The perspectives explored encompass knowledge and experience that could be made for better understanding of the issues. Going beyond showing sympathy to bereaved children, teachers can embrace approaches to improve healthy grieving and resilience. Early intervention is crucial in helping children to heal and grow from a recent bereavement (Auman, 2007). Yet, what approaches should practitioners be using to help children understand death and their grief?

Rooted in theory, there may be commonalities in the processes and phases of grief; however, everyone grieves differently and at their own pace (Mallon, 2011). The realm of children's grief is unforeseeable. In aiming to tackle the abnormality around grief, this paper focuses on the following definition: "Grief can be defined as the response to the loss in all its totality - including its physical, emotional, cognitive, behavioural and spiritual manifestations and as a natural and normal reaction to loss" (Hall, 2014, p.7). Notably, this paper uses the terms 'grief', 'mourning' and 'bereavement' interchangeably. However, there are distinct differences among them. Bereavement refers to the state of having experienced the death of a loved one (Mallon, 2011). The natural reaction to this loss can be described as grief: where external expression is mourning (Hall, 2014; Mallon, 2011).

When bereaved, children can often internalise their grief and can lack skill in verbalising their emotions (Auman, 2007). The age and stage of a child matters. At early stages of schooling, children have a grasp of death and its finality (Zach, 1978). Research has indicated that children begin to acquire the cognitive concept of death at a young age despite their rare exposure to grief as a lived experience (Gabb, Owens and MacLeod, 2013; Hunter and Smith, 2008). Many myths, such as children do not grieve and children recover quickly from grief, are challenged by researchers; however, many models on children's cognitive understanding of and emotional responses to death and bereavement do not outright reject this. Children's understandings of death can often be listed according to common developmental ages (see Cruse Bereavement Care, n.d.). The interconnectivity between children's grief and their stage of development is well evidenced (Auman, 2007; Scottish Partnership for Palliative Care, 2018). Yet, such guidance needs to be used with caution. No two children are the same; no two children will develop in the same way; and no two children will be similar with their grief. Children's grieving processes are often non-linear and grief can be submerged and then reemerge in varying intensities for months or years (Auman, 2007). The role of grief may have elements of linearity but is often filled with overlapping, 
and sometimes contradictory, emotional states and phases. Children will internalise their grief and verbalise their emotions in different ways and at different ages/stages. Working through grief can be painful, emotionally draining and helpful (Gunn, 2009); ultimately, this should highlight the need for much more attention and care to be given to this topic. It is not enough to say: 'they'll get over it'. The approach taken should consider the individual: their age; understanding of and ability to conceptualise death; personality; resilience; development; the circumstances surrounding the death; and the being they are (not becoming) (Cerel, Fristad, Verducci, Weller and Weller, 2006; Raveis, Siegel and Karus, 1999; Rotheram-Borus, Stein and Lin, 2001).

There are clear themes between many theories and models of grief, especially those by Lindemann (1994); Parkes (1976); and Worden (1991). Worden (1991; 1996; 2009) provides four tasks of mourning:

1. to accept the reality of the loss;

2. to process the pain of the grief;

3. to adjust to a world without the deceased;

4. to find an enduring connection with the deceased in the midst of embarking on a new life.

Furthermore, and similar to this staged pattern, Lindemann (1994) identifies five major categories with a focus on emotional detachment from the deceased and adapting to a new environment: somatic (physical) distress; preoccupation with the image of the deceased; guilt (relating to the deceased or to the circumstances of the death); hostile reactions; loss of patterns of conduct. This is confirmed by many other theorists where grieving is said to include, not exhaustively: numbness and anger, yearning and searching, disorganisation and despair, reorganisation; shock, denial, searching, despair, anger, anxiety, guilt; depression; withdrawal, anxiety, alarm and panic (Dyregrov, 2008; Wells, 1988). A common limitation with these models is that they often seem to follow an order, yet grieving is non-sequential (Hall, 2014). The danger with explaining the processes of grief in such a way is that many teachers may think there is a simple linear pattern.

However, on the other hand, Parkes' (1998) theory of grieving - which is similar to that of Bowlby's Theory of Attachment $(1973 ; 1980)$ as they both identify phases of bereavement highlights the overlapping and flexible nature of grief. They both explicitly illustrate a merge of phases where one replaces the former. This flexible interpretation should progress with the mindset that everyone will undertake these stages/phases at their own pace. Bereavement is unique and must be addressed individually (Holland, 1993). Grief is complicated and respecting the individual's journey is vital in child-centred approaches (Lohnes and Kalter, 1994).

The role of teachers has evolved drastically from 'purely' teaching to also taking on the responsibility for the welfare of children and young people (Abdelnoor and Hollins, 2007; Holland, 2007). This view is a matter for parents, teachers and other working professionals alike; schools have a duty of care to support children and young people who are dealing with significant loss or change. The Education (Scotland) Act (Scottish Government, 2016) identified bereavement as one of the factors where children or young people may require additional support. Most schools, at any given time, will have a recently bereaved child on their roll (Holland, 1993). However, the concepts of death and dying are often non-existent within the school curriculum (Gunn, 2009). A taboo about death still exists. It is often the forgotten about or ignored topic. Further to this problem, policy does not seem to address it. Terms such as 'death', 'dying', 'bereavement' or 'grief' do not appear in Scottish educational policies - such as Curriculum for Excellence (CfE) and Getting it right for every child (GIRFEC). This is problematic. There is very little evidence which provides clarity about the kind of support bereaved children might need. It brings to the forefront the need for this review to address approaches which should be present in educational policy to assist teachers in supporting bereaved pupils' health and wellbeing. 
The psychoeducational approaches, which teachers working with school-aged children could take, will become available through this review process. This research does not aim to provide a checklist, yet it does provide a profile by offering insights. What educationalists know, do, and care about matters for our children and young people (Hattie, 2003). Grieving children are present within our classrooms today, yet they can be silenced by teachers. Staff in schools report finding 'death' difficult to explain to children and, on the whole, they don't feel comfortable addressing the topic (McGovern and Barry, 2000). Thus, children can be left in the unknown. Approaches to death and dying can make a difference to the lives of all, and recently bereaved, children.

\section{Self-Reflexivity and Positionality}

In supporting bereaved children, as a teacher, I frequently found myself caught in a harsh spotlight. Often, I felt helpless, useless and ignorant of the right thing to say and do. A key question I continuously asked was: What approaches should I be taking to ensure bereaved children are supported in school? As a result of my own experience, in this paper, I document my own transformative journey as a teacher. I develop this by carrying out a systematic review to concrete the most common approaches for teachers to routinely help bereaved children and to highlight the need for this to be higher on the agenda.

The rationale for using retrospective autoethnography within the systematic review process is to recognise that tackling the notion of the 'forgotten mourners' needs to begin in the classroom and with the experiences which are present (Auman, 2007; Holland, 1993). To pave the way forward, this review explores approaches which encourage bereaved children to grow and to learn to live with loss - such as death of a parent, brother, sister, friend or other loved one. The aim of this study is to try and progress the field by synthesising the available research which captures the experiences and perceptions of those supporting bereaved children and the views of the children themselves. Illustrated by Auman (2007, p.35): "[There is] an alarming lack of understanding about childhood bereavement and children's need for bereavement support...". The retrospective autoethnography element enables me to position myself as a teacher. As a reflection tool, it acts as an ignition to systematically re-examine approaches in order to learn from them. In journeying to the centre of myself, I explore my own anxiety around this topic. With the dual role of researcher and teacher, my research seeks to discover unique and common perspectives among grieving children and those directly involved in their lives. I do not wish to remain outside of my data; and therefore, from the perspective of personal experience (speaking from the inside-out), I express circumstances taking place in a classroom setting. This position, which many teachers will find themselves in and be able to connect with, is aimed at showing the relationship between the reviewed data and day-to-day practice. It will also show that the approaches are necessary as this could happen in any classroom, on any given day; only when I found myself in this situation did I become aware of supporting children through change and loss.

Education is ever-changing: never static. Yet grief is a recurring phenomenon that is, and always will be, in every school. My journey is a story of only one school; this systematic review provides approaches to help many. My personal experience of supporting a bereaved child is illustrated through autoethnographic vignettes which are progressed by Pitard (2016; 2017). 


\section{Retrospective Autoethnography}

\section{Context:}

I had not anticipated that an eleven-year-old child in my class would experience the death of a sibling, having less than two years ago lived through the death of her Mum. Not only was I shocked by these events, yet I was also distressed by my own confusion in caring for and supporting this child. As a key individual in her life (class teacher), I wanted to tackle this bereavement both sensitively and meaningfully. Looking back, this story has evolved me professionally and emotionally. I soon noticed that children do not have a taboo about death: many adults - recently including me - do.

I will tell a story of supporting and teaching this child, and many others, at the time they experienced the death. As pupils in my class, their health and wellbeing was my primary concern. I understood that I played an important role in this child's grief and I opened my mind to the possibility of making a difference to her life at a time of need.

\section{Note: Any names used are pseudonyms.}

\section{Anecdote:}

As I entered the classroom on the morning after the death, there was an empty feeling. I noticed that Emily had decided to come to school that day. As I spoke to the class, I saw tears in their eyes. I paused and took a moment to myself. In this moment, I didn't know what to do, what to say and how to cope. I just kept going. What was the right thing to say? I continued on as normal, yet I felt frustrated that I was silencing the grief. The others were lost in their emotions. It soon became clear that I had to do something about what could only be described as an 'elephant in the room'. I looked at Emily who was troubled and fearful. I smiled. The smile was returned, and it spoke a thousand words. No problem was solved but comfort and safety were there. I remained silent: feeling empty and blue.

My initial step forward was speaking to Emily. The word 'died' was particularly tough to use. I still felt helpless at this point but being by her side was powerful. Her face lit up and a hug spoke more than words. For the rest of the day, I watched and wondered. I wanted to listen to the grieving voices of the children by providing happy times and positive memories to reflect on while attending to their emotions of sadness and fear.

\section{Emotional Response:}

I felt so overwhelmed. I began to question my ability to meet the needs of all children within my care. What else could I do? I needed to talk about it and let go of my sadness. But I didn't.

The children soon let out their thoughts and feelings: chatter filled the room. I felt sad for everyone; I wanted to make it better. I was weighed down by the low emotional wellbeing of my pupils despite life carrying on as normal.

Hearing the words, "I don't really know how I feel that my mum and brother have died," from a young child is deeply upsetting. I didn't want to distress Emily more by talking about it. That was until she asked, "Why does nobody talk to me about it?" She described one of the biggest feelings of bereavement as loneliness. 


\section{Reflexivity:}

Initially, I used my professional judgement to try and find answers. But, being present was the most important. I was at my most nurturing when I was honest about what had happened and honest with myself. In turning the lens back, I realise I didn't have the confidence or bravery to respond in the way I wanted to. I let the fear of upsetting and the assumption that there was a 'right' thing to do get in the way. I felt a responsibility of holding and containing the class and thus resorted to continuing to teach. I wanted to give everyone the chance to express themselves but felt unprepared for what might then happen. As a result of this, I often experienced professional isolation. The practice of reflexivity has enabled me to open myself to an understanding of child bereavement. I was in a position where I placed high expectations on myself whilst doubting I had the skills or endurance to fulfil these. I understood that my own well-being required emotional support too. Then, I could achieve what I wanted to.

\section{Strategies:}

In learning new ways to respond to death, I found there was a clear need to explore the impact of change and loss on everyday life. By combining psychology and education, within a child-centred approach to learning, I have come to terms with supporting children who are bereaved. I was scared of using the language around death and dying in case of hurting one's feelings and unintentionally upsetting, but sensitivity aligned with truth and honesty can provide comfort. This personal experience was the catalyst for my interest in this topic. Instead of letting children silently grieve, I now build on healthy curiosity: listening to the child's thoughts, beliefs, fears and questions about death.

\section{Methods}

A systematic literature search was undertaken in Winter 2018 and again in Spring 2019. Four electronic databases were searched. These were: British Education Index; Child Development \& Adolescent Studies; ERIC; and PsycINFO. Search terms used across the databases included: bereavement, grief, death, approaches and school combined with search terms related to children and young people. Specifically, an example of a search is as follows: child*; student*; death; bereavement or grief or loss; primary school or junior school or elementary school. Furthermore, reference lists, Google Scholar searches (first 10 pages) and SuPRIMO were also used to identify literature in the field and scanned to locate additional relevant studies.

Cross-sectional studies, in peer-reviewed journal articles, were included to robustly obtain only empirical findings that were highly reliable. This decision was made to focus on beliefs and experiences related to approaches for supporting bereaved children and thus develop an understanding around complex social phenomena. It is assumed that alongside the retrospective autoethnography this review strategy will make visible the voice of the researcher in-line with the data. The reflection and systematic process go hand-in-hand in judging the quality of the published research.

The review inclusion criteria were studies: (a) published after 2000; (b) published in English language; (c) using qualitative methods of data collection; (d) involving bereaved children and young people aged 3-18 or those working directly with; (e) related to children and young people grieving the death of a parent or sibling or other loved one.

Notably, studies did not exclusively have to link to the school and classroom environment. It was felt that many approaches would be transferable, and a holistic view would consider how bereavement is approached across settings. This included a lens focused on a better understanding of how children cope with grief internationally. To capture the most 
appropriate evidence for children of today's world, articles published 2000 onwards only were included. Moreover, studies without identifiable qualitative methods of data collection and outcomes were excluded on the view that findings - ideas, concepts and metaphors could not be compared across different studies in a coherent way (Britten et al., 2002). The quality of this review was enabled by piloting the inclusion criteria with specific focus on the research aims.

During the selection process, abstracts of all retrieved studies were examined. Initially, 765 publications were collected. Titles and abstracts were read at this screening stage and 727 records were excluded. When in doubt, the entire article was accessed and read. After duplicates were removed, 38 articles met the inclusion criteria for the content of this review. All of the 38 articles were retrieved and reviewed in full. The inclusion criteria was applied to the full text and 23 articles were excluded. The final set of includes was 15 articles - all of which were cross-sectional in design. Figure 1 presents a PRISMA flowchart (Moher et al., 2009) to illustrate the different phases of the systematic review search. The majority of the articles were excluded as they were not topic related, not linked to approaches for school aged children or not cross-sectional in design. The initial criteria was revised at title and abstract stage because it was too restrictive on the type of bereavement (the first attempt excluded 758 articles). It was broadened to encompass 'death of a loved one' rather than limiting it to 'death of a parent or sibling'. The impact of a bereavement is personal to the child and only including parent or sibling deaths in this paper would not represent all children's experiences.

\section{(Fig. 1 - Flow diagram of search outcomes)}

The handling of data followed a qualitative enquiry model. Alongside the systematic review protocol, this paper uses analysis phases to explore Noblit and Hare's (1988) seven-step process for conducting metaethnography. Thus, a qualitative enquiry model has been created for the purposes of this review (see Figure 2).

\section{(Fig. 2 - Qualitative enquiry model developed to be used as review protocol)}

It was clear that, after appraising individual studies included in the review (see Table 1), the strength of evidence was appropriate and thus a synthesis translation table was used for data extraction from the relevant studies (see Appendix 1). The synthesis translation table comprised all relevant concepts from each paper. This included details about the setting, participants, bereavement and type of study carried out. Key themes have been identified, explored and then summarised across studies.

Table 1 Ratings of the appropriateness of included studies (adapted from Liabo, Gray and Mulcahy, 2013).

To combat the decontextualisation of descriptive data, the synthesis table is included to show the reader the exact data extracted from each article. Furthermore, biases for each individual study were considered alongside bias across studies to ensure validity of their findings. Generally, studies used random sequence generation groups (comparability is therefore grounded). The selection of participants was fair and sensitive to those who had recently been bereaved. The findings in all studies described experiences and perceptions, and this was reflected in the completeness of outcome data where selective reporting was not evident. The sensitivity and uncertainty around this topic did, understandably, mean participants were vulnerable and careful ethical considerations were accounted for. Loss of participants was expected, natural and understandable - this was declared within all studies, with appropriate reasoning. 


\section{Results}

A range of data collection methods were used across the studies: ethnographies (2); observation (1), case study (1) and interviews (11). Over half of the studies focused on working with children and young people: with a small number also collecting data from their surviving parents/main carers. Three studies (Dyregrov, Endsjø, Idsøe and Dyregrov, 2015; Lane, Rowland and Beinart, 2014; Lowton and Higginson, 2003) interviewed teachers (including five primary and secondary head teachers). Recruitment for participants was school-related in four studies (Dyregrov et al., 2015; Lane et al., 2014; Lowton and Higginson, 2003; Reid, 2002); through bereavement services in three (Brewer and Sparkes, 2011a; Brewer and Sparkes 2011b; Bugge, Darbyshire, Røkholt, Haugstvedt and Helseth, 2014); through hospitals, obituaries and organisations in five (Andrews and Marotta, 2005; Brooten and Youngblut, 2017; Nilsson and Ängarne-Lindberg, 2016; Søfting, Dyregrov and Dyregrov, 2015; Thompson et al., 2011); and a further three studies took place in grief camps (Keeley and Baldwin, 2012; McClatchey and Wimmer, 2012; Richardson, Ferguson, and Maxymiv, 2017). 33\% of the studies were UK based and $67 \%$ reported international findings. Most studies were conducted in the United Kingdom [5] (Brewer and Sparkes, 2011a; Brewer and Sparkes 2011b; Lane et al., 2014; Lowton and Higginson, 2003; Reid, 2002); and United States [5] (Andrews and Marotta, 2005; Brooten and Youngblut, 2017; Keeley and Baldwin, 2012; McClatchey and Wimmer, 2012; Richardson et al., 2017); one in Sweden (Nilsson and Ängarne-Lindberg, 2016); three in Norway (Bugge et al., 2014; Dyregrov et al., 2015; Søfting et al., 2015); and another was a collaborative study involving Canada and the United States (Thompson et al., 2011). Of those involved in the studies, the majority of the participants had been bereaved of a parent or sibling. Four studies detailed bereavements as 'family death', 'loved one' or, in some cases, the deaths were classified as varied (Andrews and Marotta, 2005; Dyregrov et al., 2015; Lowton and Higginson, 2003; Richardson et al., 2017). Two articles (Reid, 2002; Thompson et al., 2011) worked with families who had encountered the death of a child.

The identified qualitative studies were analysed using an enquiry model rooted in metaethnography. The synthesis translation and extraction stages included raw data from participants and also discussions of the data from the authors of the studies. This review analysed a breadth of data which considered perspectives on parentally bereaved young people, sibling death, children who died from cancer and death of a loved one. It aimed to tackle a hierarchy around the impact of a death on a young person and focused on the effects of death and dying in its entirety.

Valuing the dialogue of all those involved in supporting bereaved children - teachers, parents and carers - was evident across studies. All interviews, case studies and observations took place in safe spaces where children felt comfortable and their feelings could be nurtured compassionately. It is worth considering that all children involved would have had different abilities to verbalise their grief (Mallon, 2011). Furthermore, teachers included in the studies were mainly women. Despite the fact this is a true reflection of the profession, male teachers are underrepresented within this research. Finally, all parents/carers who took part in the research were directly impacted by a bereavement and therefore were also dealing with their own grief as well as supporting their children.

A key research question for this review is: What approaches are used in the studies to help children cope with death? Most approaches taken were based on showing love, building resilience and helping children live with grief. The findings represent how approaches are used in different settings such as schools, camps and family communities. Looking outwards is appropriate as children may express their grief in different ways in different environments. The core themes resulting from commonalities across the main findings of the studies were:

- Communication

- Peer/Social Support 
- Expressing Emotion

- Role of Adult (Including relationships)

- Conceptualising Bereavement (Meaning Making)

- Finding Comfort

- Stress and Trauma

- Looking to the Future

The themes which are present in individual articles are outlined in Table 2 (below). Figure 3 illustrates the reporting trend of the themes across time. It is clear that for the majority of the studies, which were published after 2010, the average number of themes reported was 5.3. This highlights the validity of the generated themes.

Table 2 Themes present in the included studies

(Fig. 3 - Chronological comparison of number of themes present in individual articles)

The retrospective autoethnography enables the reader to look inwards: to the school environment and think deeply about what approaches teachers can facilitate. The findings of this systematic review are outlined in the synthesis translation table (see Appendix 1) where direct quotes and paraphrasing are used. Eight main themes were identified in the process:

\section{Communication (13)}

The results showed that talking about the deceased can be difficult, yet parents voiced in interviews carried out by Bugge et al. (2014) that their surviving children liked to talk as it provided comfort and security by keeping memories alive. There is often an 'awkwardness' around this and children can feel ignored when not listened to. The results of Brewer and Sparkes (2011a) yields towards getting children to talk about grief. Some participants expressed that talking about death becomes a part of daily conversations in an open and honest way. Findings highlight that being comfortable with communicating to bereaved children requires addressing barriers around lack of confidence. Three studies highlighted the role of communication in working with the child's immediate family structure. Dyregrov et al. (2015) provided evidence of a necessity for schools to have a response action plan: 'a formula' for dealing and communicating with parents/carers when a child is bereaved. However, no direct evidence was given around the efficacy of this approach. In fact, the data showed participants to be very sceptical.

\section{Peer/Social Support (8)}

Evidence given on participants' experiences and perceptions found in Brewer and Sparkes (2011a) showed that connecting with others who had lived through similar situations to their own yielded significant effect on the wellbeing of the bereaved. Many participants felt that this gave them a sense of belonging and that they were 'not alone'. One study used healing circles to develop social support during emotionally intense discussions. There is a small evidence base to suggest this empowered the young people to comfort self and others through a social-perspective focused on empathy. However, there was a reasonable amount of evidence given in studies by Lane et al. (2014) and McClatchey and Wimmer (2012) to conclude that friends of the bereaved felt anxious: often around wanting to help their friend but not knowing how to.

\section{Expressing Emotion (14)}

Two studies discussing emotion identified overwhelming sadness and anger felt by bereaved children - one goes on to discuss fear and enjoyment. The information provided by Thomson et al. (2011), working with a large number of parents and surviving siblings, illustrates that children should be aware of no expectations about how one should or should not feel. The participants across studies felt that self-acceptance was important and achieved when they were able to channel and attend to emotional chaos. Children in studies felt like they had to 
'hold it back' or couldn't 'put it anywhere'. The facilitation of an emotional space which teachers used informally and formally was welcomed. Notably, evidence suggested that children's reactions can be erratic, confusing and painful to witness. There was no significant awareness of how this was dealt with by teachers. Nonetheless, participants felt that provided space (physically and psychologically) helped them to express their grief. There was little evidence to suggest that it was difficult to provide emotional support within the school day. This only involved one case study and the evidence appears weak.

\section{Role of Adult (Including relationships) (11)}

Parents, teachers and children across studies voiced the importance of normality (yet being adaptive). Evidence supported providing children with routine through security and predictability. Individuals included in the studies perceived that teachers have a role in providing children with coping strategies. One case study (Reid, 2002) portrayed a concern in bereavement being unacknowledged by staff in schools. Information regarding why this may be the case was shown in the study by Lane et al. (2014) as teachers feel helpless and useless of the right action to take. Teachers felt that they were becoming counsellors and a misunderstanding of their role was evident. Across studies, participants stressed that the role of the adult was to listen, be available, be present and reduce anxiety. The results of Søfting et al. (2015) echoed many professionals in that children are never too young to grieve. Children wanted adults to attend to this by having conversations around death and rituals with them.

\section{Conceptualising Bereavement (Meaning Making) (12)}

The children involved in the research felt empowered when they were taught grief terminology. Through observations, children were seen to experiment with coming to terms with the death of their loved one. Nilsson and Ängarne-Lindberg's (2016) data gathered through interviews suggested that children often do this with someone who isn't experiencing the death directly. In one particular case, the use of language by one child stunned a class to silence and the teacher 'moved on' (Lowton and Higginson, 2003). Teachers and parents expressed that being clear that death is final and explaining what this means and where the deceased has gone is important. Furthermore, four studies (Andrews and Marotta, 2005; Brewer and Sparkes, 2011a; 2011b; Bugge et al., 2014) involving children and parents agreed that metaphors were helpful for making sense of the bereavement. Evidence from one study showed an indication that parents believed their child was 'too young to grieve'. However, this study involved a small number of adult participants and the impact of death on their children was not directly measured to support the finding.

\section{Finding Comfort (12)}

Reporting found significant ways to help children find comfort. These related directly to the death in ways such as: reflecting through religion and faith (praying, thinking of heaven and remembering 'God's plan'); continuing a relationship with the deceased (using photographs and videos); and celebrating the life of the loved one regularly. Results also indicated that comfort was found in taking time to have fun in new activities, through recreation, physical activity and finding humour.

\section{Stress and Trauma (7)}

Mixed results were gathered across studies in relation to managing stress. Participants expressed a degree of trauma, but this varied from child to child. Mostly, this related to fear of experiencing a similar situation and death of living family members. Reid (2002) and McClatchey and Wimmer (2012) showed participants felt small but negative effects on their schooling: behaviour and attainment. Although, no evidence suggested that school performance was affected and approaches were not directed at this. Some studies showed children's symptoms of intrusive grief to include depression, anxiety and panic attacks. Findings from school staff within Lowton and Higginson's (2003) interviews concluded that reaching out to counselling services only addressed these issues short termly. Two 
respondents stated that long-term approaches require the school and family to work together.

\section{Looking to the Future (8)}

Most studies focused on positive changes, an appreciation of life and moving forwards. Keeley and Baldwin (2012) showed an importance of the family 'journey'. Participants in one study felt that some approaches were unrealistic, such as: 'move on with your life'. The data illustrated how children perceived themselves - with many participants increasing their appreciation of life over time. A study showed the difference a forward-looking approach can have: one participant discussed the 'wall' which had gone as a result of being optimistic.

The extracted data was translated to outline the relationships of the studies to one another. Across the 15 studies, the translation compared themes and concepts from each paper (where the synthesis of the former articles was compared with the following). Across the findings, some accounts were directly comparable (reciprocal) whilst others stood in relative opposition to each other (refutational). The articles agreed on the role of peer support, means of expression, metaphors and attuning to the needs of the individual: giving children the space and time they need to process their emotions. The 'taboo' around death was present in schools, yet it seemed that educators felt they had a role to consider what the child needs from them. In comparison, it was clear that a structured plan was not favoured by all and how schools worked with bereaved children was inconsistent. Short term targets were put in place, and consequently addressed, but the long-term support was overlooked. This seemed to be down to teachers feeling too much burden was placed upon them and they feel lack of training is a barrier. Finally, new ideas were built together and understood (line of argument). Talking about death and living with grief was beneficial in normalising feelings and emotions. A consideration of the child's social world explored how curiosity, language, peers, family and specialists could form a supportive network. Approaches focused on being (not trying to fix or rescue but having a presence as the child works through their grief) and becoming (looking to the future and embarking on a new life without the deceased).

\section{Discussion}

The aims of this article were to systematically review data around supporting bereaved children. The review found that research on approaches used to support bereaved children is significantly limited. The synthesis of articles illustrated implications for teachers by explaining what approaches help children cope with death and dying. Fifteen studies were included in this review; however, only four took place in schools and involved teachers. All studies used qualitative methods of data collection; mainly, this involved interviews with the exception of one case study, two ethnographies and one observational enquiry. Moreover, most identified studies involved a small sample size, except one study which reached out to 40 families. The review found that all studies provided rich evidence on approaches used to support children who are grieving. The gathered data was child-focused - where the impact on the children was clear and implications for teachers could be concluded. The findings, in line with the research aims, are indications of promising approaches rather than evidence of effect. The issue of the outcomes is potentially contentious as some teachers may feel there is too much burden already placed upon them and expecting them to have counselling skills is one step too far. Nevertheless, the priority is on influencing the matters that concern our children and young people by empowering them with new knowledge and understanding to act and voice their worlds. This review is the first attempt to systematically consider approaches to death and dying with a specific focus on teachers and schools. 
Common approaches encapsulated the views of bereaved children and those caring for young people, including parents/carers and teachers. The perceived common approaches are outlined in Table 3.

\section{Table 3 Description of common approaches}

Schools have a unique role in helping grieving children. The majority of the studies suggested approaches with psychoeducational components relating to curriculum development, pedagogy and teacher training. The use of metaphors can help children understand the many changes which are set in train when someone dies. This has been shown to help children manage their grief much more positively (Mallon, 2011). A rich symbolic curriculum design can underpin approaches in schools, particularly through use of connecting children with their peers. Valuing peer support as a coping mechanism can avoid social isolation which death can bring about (Ellis, Dowrick and Lloyd-Williams, 2013). Children, however, do lack the knowledge and skills to support bereaved peers (Stylianou and Zembylas, 2018a). Introducing children to death issues through the school curriculum can prepare them for supporting a bereaved peer. Furthermore, facilitating whole class and group opportunities builds a network of children who reach out to one another as their situations parallel. This is not surprising as it is reassuring when connecting with others with whom one is alike. A natural response to death, regardless of the circumstance, brings a chaos of emotions (Mannarino and Cohen, 2011). Teachers, in most cases, are committed to giving children the space and time they needed to express their emotions. If teachers adopt a pedagogical approach where they give children the opportunity to explore grief and grieving, with care and sensitivity, then an understanding of death in cultural and religious contexts will help children manage emotional responses when bereaved (Stylianou and Zembylas, 2018b). As someone who is not directly involved in the bereavement, pupils find trust in staff being regularly available to listen. A positive approach was favoured by the majority of participants - especially when considerations around death, dying and bereavement were encouraged as part of the school curriculum. This can be key in helping children move from death denial to death acceptance (Stylianou and Zembylas, 2018b; Wong and Tomer, 2011).

The overall results suggested that educating children around this topic is vital. The need for grief terminology to be taught is supported by evidence that children are not equipped with the language around death and dying: particularly when trying to help a bereaved friend. Moreover, the effects of teaching coping strategies to all children assisted in normalising grief and helped children to readjust. In most cases, participants used analogies such as 'a journey' which implicitly referenced cycles of grief such as those outlined by theorists KüblerRoss (1969); Lindemann (1994); Parkes (1976); and Worden (1991). Permission and honesty should underpin approaches in schools to give children a positive outlook in life and support them to dip in and out of their grief.

Despite the research highlighting many ways in which adults could approach the topic of death with children and young people, the results suggest a taboo still exists. In schools, talking about a death tends to happen between children and this does not involve staff (Paul, 2019). Adults may be modelling an avoidance approach and giving the impression it makes them feel uncomfortable (McGovern and Barry, 2000). This would consequently be the case for how the child engages with the death: the child may feel that they have to internalise as they model their behaviour on perceived normative structures (Szmigin and Canning, 2015). However, in this realm, children's views are absent and unacknowledged. The studies in this review have shown that children can talk about death. It is often the social domain that surrounds the child - school staff and family members - who have a taboo about death (Paul, 2019). 
Although many experiences and perspectives were common across studies, some differences were apparent. Mixed and inconsistent results found some studies reporting that some children were 'too young to grieve'. Furthermore, there was no direct link shown between attainment and behaviour in school and being bereaved: despite a minority of studies suggesting this link was important to consider. The role of the teacher in adopting sensitive approaches was compared to that of a counsellor. However, most studies acknowledged a difference and teachers must recognise themselves as the educator - and not the counsellor. Finally, participants were sceptical about schools using pre-planned actions as an approach. Lack of teacher training and confidence in tackling these issues may have a part to play in these views.

The majority of studies found that outcomes in child bereavement encompassed a range of factors including, but not extensive to: physical, emotional and mental health; bullying; suicide; attainment and achievement; self-esteem; resilience. Subsequently, approaches to tackling these issues were outlined. To meet these needs, teachers are required to work as part of the family network. Because children spend a great deal of their childhood in schools, teachers have an important role in helping children to understand death, to communicate feelings, to recognise that grieving will never finish and to regain control of their lives.

\section{Implications}

Death and dying will affect every person at some point in their life. With more than 45,000 children in the UK bereaved of a parent every single year (Winston's Wish, n.d), this topic should be at the forefront of our school's priorities. This review has sought to highlight the most common approaches used to routinely help bereaved children and explore implications for teachers. In doing so, it has highlighted the need for this field to be given much more attention in schools. Pupils are being silenced, ignored and turned away of the support they need. Teachers can, if taking appropriate action, ensure children grow and heal from significant changes and losses in their life.

School is often a safe place for bereaved pupils which, at a time of fear and uncertainty, brings normality and security. Support in schools needs to be directed at pupils, teachers and families. Leadership and Management Teams within schools should: tackle staff confidence in supporting pupils dealing with death; develop school bereavement policies; and put in place a rationale for facilitating lessons around death and dying (Scottish Partnership for Palliative Care, 2018). Many specialist services such as Child Bereavement UK, Winston's Wish and Richmond's Hope provide resources to give teachers practical strategies and activities for working through children's grief. However, the approach which the school takes should also value understanding and be consistently clear to all staff.

Findings confirmed that to provide adequate support teachers should provide normality, a listening ear, coping strategies and opportunities for children to their express emotions. In addition to this, schools can ensure they are being proactive by working with parents/carers and teachers to create guidance. Suggestions are that teachers work closely with the bereaved family to support the child's learning, health and wellbeing in school. The role of the teacher needs to be clearly set out as they will be the prime supporter for the child. In some cases, however, children may require additional agencies to intervene. It should also be within the remit of the school to provide this information to families. Additionally, and as part of daily school life, teachers can create and facilitate support groups which use peers and social skills to significantly influence children's outcomes. Furthermore, the power of conversations should not be underestimated. Both informal and formal conversations with all children around death, dying and bereavement will undoubtedly provide a space for children to build up resilience - and not reliability. 
The retrospective autoethnography expressed my anxiety around supporting a recently bereaved child within my class. I was stunned of what approaches to take: what to say, what to do, what support to give. Unintentionally, I resorted to not acknowledging the situation and therefore not attending to the present grief processes. In bringing together my experience of being a teacher with the approaches this systematic review recommends, a metaphor of a seasons cycle can be imagined. It shows that grief can fall suddenly and often unexpectedly like autumn leaves. I, as a teacher, had many questions about child bereavement. In the initial stages, the bereaved child in my class was in a state of turmoil and I couldn't help but feeling lost and getting caught in my own emotions. Darkened winter moved to spring and I connected with the child through a range of approaches. Over time, the child began to feel supported and hope was restored. No longer will I ignore the topics of death and dying as they present themselves in the classroom. By not turning away, I can show that winter doesn't last forever: and summer will come.

Although this review identified a broad range of perspectives, there may be some knowledge gaps. Findings have confirmed that more studies are needed in school settings focused on children and what matters to them. Creatively designed instruments are needed to particularly enable young bereaved children to express their thoughts, feelings and ideas around death and dying. Future research should also consider groups of children who are vulnerable as a result of other circumstances and the impact of bereavement in this perspective.

\section{Limitations}

This study has some limitations. A major limitation is that only one reviewer carried out this research and therefore this may impact on the rigour of the findings. A review team or external quality assurance procedures could have strengthened and enhanced the quality of the study. However, this was not possible as the research was part of a larger doctoral project. Secondly, the inclusion of data that was collected through qualitative methods, published after 2000 and in peer-reviewed journals may result in a potentially biased presentation of conclusions. Only articles in the English language were used in this review and this may not represent all evidence around this topic. This review referred to a limited amount of countries and applying the results to children with various cultural backgrounds may be inconsistent. However, to ensure transparency, the countries involved were stated. Furthermore, of the fifteen included studies, only four took place in schools. Looking into a range of environments was appropriate to represent a holistic view of how children are supported. However, this could raise questions on generalisability. All findings may not easily be transferred to school settings as suggested. Finally, because of the use of metaethnography as a synthesis tool some may argue against the trustworthiness of the findings. Despite this, synthesis techniques were applied rigorously to ensure that the crosssectional designs were reviewed in line with the research objectives.

\section{Conclusion}

The results of this systematic review consider what approaches can be taken in schools to help children cope with death and dying. This research recommends important implications for teachers. It highlights that death is an important part of every class and, with appropriate support, teachers can make a difference to the lives of bereaved children. The approaches are developed to give children better knowledge and understanding of death and to give support to those directly experiencing it. The approaches are presented to have practice and policy implications which, if addressed, may help to protect children against adverse effects of bereavement. 


\section{Conflict of Interest}

There is no conflict of interest.

\section{Data Availability Statement}

The data that support the findings of this study are available from the corresponding author upon reasonable request. 


\section{References}

Abdelnoor, A. \& Hollins, S. (2007) The effect of childhood bereavement on secondary school performance, Educational Psychology in Practice, 20(1), 43-54.

Andrews, C. R. \& Marotta, S. A. (2005) Spirituality and Coping Among Grieving Children: A Preliminary Study, Counselling and Values, 50(1), 38-50.

Auman, M. J. (2007) Bereavement Support for Children, The Journal of School Nursing, 23(1), 34-39.

Bowlby, J. (1973) Attachment and Loss: Separation, Anxiety and Anger (London, Hogarth Press).

Bowlby, J. (1980) Attachment and Loss: Sadness and Depression (London, Hogarth Press).

Brewer, J. D. \& Sparkes, A. C. (2011a) Parentally bereaved children and posttraumatic growth: Insights from an ethnographic study of a UK childhood bereavement service, Mortality, 16(3), 204-222.

Brewer, J. D. \& Sparkes, A. C. (2011b) Young people living with parental bereavement: Insights from an ethnographic study of a UK childhood bereavement service, Social Science \& Medicine, 72(1), 283-290.

Britten, N., Campbell, R., Pope, C., Donovan, J., Morgan, M., \& Pill, R. (2002) Using meta ethnography to synthesis qualitative research: a worked example, Journal for Health Services Research \& Policy, 7(4), 209-215.

Brooten, D., \& Youngblut, J. M. (2017) School Aged Children's Experiences 7 and 13 Months Following a Sibling's Death, Journal of Child and Family Studies, 26(1), 11121123.

Bugge, K. E., Darbyshire, P., Røkholt, E. G., Haugstvedt, K. T. S., \& Helseth, S. (2014) Young Children's Grief: Parents' Understanding and Coping, Death Studies, 38(1), 36-43.

Cerel, J., Fristad, M., Verducci, J., Weller, R.A., \& Weller, E. B. (2006) Childhood Bereavement: Psychopathology in the 2 Years Postparental Death, Journal of the American Academy of Child and Adolescent Psychiatry, 45(1), 681-690.

Crawford, C. C., Boyd, C. C., \& Jonas, W. B. (2015) Systematic reviews in practice (Virginia, Samueli Institute).

Cruse Bereavement Care. (n.d) Children's understanding of death. Available online at: https://www.cruse.org.uk/get-help/for-parents/childrens-understanding-of-death (accessed March 2019).

Dyregrov, A. (2008) Grief in Children: A handbook for adults (London, Jessica Kingsley).

Dyregrov, K., Endsjø, M., Idsøe, T., \& Dyregrov, A. (2015) Suggestions for the ideal followup for bereaved students as seen by school personnel, Emotional and Behavioural Difficulties , 20(3), 289-301.

Ellis, J., Dowrick, C., \& Lloyd-Williams, M. (2013) The long-term impact of early parental death: lessons from a narrative study, Journal of the Royal Society of Medicine, 106(1), 57-67. 
Fauth, B., Thompson, M. and Penny, A. (2009) Associations between childhood bereavement and children's background, experiences and outcomes (London: National Children's Bureau).

Gabb, E. M., Owens, G. R., \& MacLeod, R. D. (2013) Caregivers' estimations of their children's perceptions of death as a biological concept, Death Studies, 37(1), 693-703.

Graham, A. (2012) Life is like the Seasons, Childhood Education, 80(6), 317-321.

Gunn, C. (2009) Bereavement Counselling and Death Education: Issues for the Pastoral Team, Pastoral Care in Education, 8(1), 4-11.

Hall, C. (2014) Bereavement theory: recent developments in our understanding of grief and bereavement, Bereavement Care, 33(1), 7-12.

Hattie, J. (2003) Teachers make a difference: What is the research evidence?, in Building Teacher Quality: What does the research tell us? ACER Research Conference, Melbourne, (Australia, University of Auckland).

Holland, J. (1993) Childhood bereavement in Humberside primary schools, Educational Research, 35(3), 289-297.

Holland, J. (2007) Child bereavement in Humberside primary schools, Educational Research, 35(3), 289-297.

Holland, J. (2008) How schools can support children who experience loss and death, British Journal of Guidance \& Counselling, 36(4), 411-424.

Hunter, S. B., \& Smith, D. E. (2008) Predictors of Children's Understandings of Death: Age, Cognitive Ability, Death Experience and Maternal Communicative Competence, OMEGA Journal of Death and Dying, 57(2), 143-162.

Keeley, M., \& Baldwin, P. (2012) Final Conversations, Phase 2: Children and Everyday Communication, Journal of Loss and Trauma, 17(4), 376-387.

Kübler-Ross, E. (1969) On Death and Dying (New York, Macmillan).

Lane, N., Rowland, A., \& Beinart, H. (2014) "No Rights or Wrongs, No Magic Solutions": Teachers' Responses to Bereaved Adolescent Students, Death Studies, 13(1), 654-661.

Liabo, K., Gray, K., \& Mulcahy, D. (2013) A systematic review of interventions to support looked-after children in school, Child \& Family Social Work, 18(3), 341-353.

Lindemann, E. (1944) Symptomatology and management of acute grief, American Journal of Psychiatry, 101(3), 141-149.

Lohnes, K. L., \& Kalter, N. (1994) Preventive intervention groups for parentally bereaved children, American Journal of Orthopsychiatry, 64(1), 594-604.

Lowton, K., \& Higginson, I. J. (2003) Managing bereavement in the classroom: A conspiracy of silence?, Death Studies, 27(8), 717-741.

Machi, L. A., \& McEvoy, B. T. (2016) The literature review: six steps to success (3rd ed.) (California, SAGE). 
Mallon, B. (2011) Working the bereaved children and young people (London, SAGE).

Mannarino, A. P., \& Cohen, J. A. (2011) Traumatic Loss in Children and Adolescents, Journal of Child \& Adolescent Trauma, 4(1), 22-33.

McClatchey, I. S., \& Wimmer, J. S. (2012) Coping with parental death as seen from the perspective of children who attended a grief camp, Qualitative Social Work, 13(2), 221236.

McGovern, M., \& Barry, M. M. (2000). Death education: Knowledge, attitudes and perspectives of Irish parents and teachers, Death Studies, 24(1), 325-333.

Moher, D., Liberati, A., Tetzlaff, J., Altman, D. G., \& The PRISMA Group. (2009) Preferred reporting items for systematic reviews and meta-analyses: the PRISMA statement. Available online at: https://www.ncbi.nlm.nih.gov/pubmed/19621072 (accessed April 2019).

Nilsson, D., \& Ängarne-Lindberg, T. (2016) Children who lose a parent suddenly: what kind of assistance do they feel provides relief? A content analysis study of children and their parents, Child Care in Practice, 22(2), 197-209.

Noblit, G. W., \& Hare, R. D. (1988) Meta-ethnography: synthesizing qualitative studies (London, SAGE).

Parkes, C. M. (1976) Determinants of outcome following bereavement, Journal of Death and Dying, 6(4), 303-323.

Parkes, C. M. (1998) Coping with Loss: Bereavement in adult life, British Medical Journal, 316(7134), 856-859.

Paul, S. (2019) Is Death Taboo for Children? Developing Death Ambivalence as a Theoretical Framework to Understand Children's Relationship with Death, Dying and Bereavement, Children \& Society, John Wiley \& Sons Ltd and National Children's Bureau.

Pitard, J. (2016) Using Vignettes Within Autoethnography to Explore Layers of CrossCultural Awareness as a Teacher. Available online at: http://www.qualitativeresearch.net/index.php/fqs/article/view/2393/3922 (accessed April 2019).

Pitard, J. (2017) A Journey to the Centre of Self: Positioning the Researcher in Autoethnography. Available online at: http://www.qualitativeresearch.net/index.php/fqs/article/view/2764 (accessed April 2019).

Raveis, V. H., Siegel, K., \& Karus, D. (1999) Children's Psychological Distress Following the Death of a Parent, Journal of Youth and Adolescence, 28(2), 165-180.

Reid, J. (2002) School Management and Eco-systemic Support for Bereaved Children and their Teachers, International Journal of Children's Spirituality, 7(2), 193-207.

Richardson, R. A., Ferguson, P. A., \& Maxymiv, S. (2017) Applying a Positive Youth Development Perspective to Observation of Bereavement Camps for Children and Adolescents, Journal of Social Work in End-Of-Life \& Palliative Care, 13(2-3), 173-192. 
Rotheram-Borus, M., Stein, A. J., \& Lin, Y. Y. (2001) Impact of Parent Death and an Intervention on the Adjustment of Adolescents Whose Parents Have HIVIAIDS, Journal of Consulting and Clinical Psychology, 69(5), 763-773.

Schlozman, S. C. (2003) The Pain of Losing a Parent, Educational Leadership, 60(8), 91-92.

Scottish Government. (2016) Education (Scotland) Act (Edinburgh, Author). Available online at: http://www.legislation.gov.uk/asp/2016/8/contents/enacted (accessed March 2019).

Scottish Partnership for Palliative Care. (2018) A road less lonely: Moving forward with public health approaches to death, dying and bereavement in Scotland (Edinburgh, Author).

Søfting, G. H., Dyregrov, A., \& Dyregrov, K. (2016) Because I'm Also Part of the Family. Children's Participation in Rituals After Loss of a Parent or Sibling: A Qualitative Study From the Children's Perspective, Journal of Death and Dying, 73(2), 141-158.

Stylianou, P., \& Zembylas, M. (2018a) Peer support for bereaved children: Setting eyes on children's views through an educational action research project, Death Studies, 42(7), 446-455.

Stylianou, P., \& Zembylas, M. (2018b) Dealing with the concepts of "grief" and "grieving" in the classroom: Children's perceptions, emotions, and behavior. OMEGA Journal of Death and Dying, 77(3), 240-266.

Szmigin, I., \& Canning L. (2015) Sociological ambivalence and funeral consumption, Sociology, 49(4), 748-763.

Thompson, A. L., Miller, K. S., Barrera, M., Davies, B., Foster, T. L., Gilmer, M. J., ... , \& Gerhardt, C. A. (2011) A Qualitative Study of Advice From Bereaved Parents and Siblings, Journal of Social Work in End-Of-Life \& Palliative Care, 7(2-3), 153-172.

Wells, R. (1988) Helping children cope with grief: Facing a death in the family (London, Sheldon Press).

Winston's Wish. (n.d.) Facts and Figures. Available online at: https://www.winstonswish.org/about-us/facts-and-figures/ (accessed April 2019).

Wong, M., \& Tomer, A. (2011) Beyond terror and denial: The positive psychology of death acceptance, Death Studies, 35(1), 99-106.

Worden, J. W. (1991) Grief Counseling and Grief Therapy: A Handbook for the Mental Health Practitioner (2nd ed.) (London, Routledge).

Worden, J. W. (1996) Children and grief: When a parent dies (New York, Guildford Press).

Worden, J. W. (2009) Grief Counseling and Grief Therapy: A Handbook for the Mental Health Practitioner (4th ed.) (New York, Springer).

Zach, H. (1978) Children and death, Social Work Today, 9(39), 11-13. 


\begin{tabular}{|c|c|c|c|c|}
\hline $\begin{array}{l}\text { Methods and concepts } \\
\text { (Reciprocal translation } \\
\text { and/or Refutational } \\
\text { synthesis) }\end{array}$ & Reid, J. (2002). & $\begin{array}{l}\text { Lowton, K., \& Higginson, I. J. } \\
\text { (2003). }\end{array}$ & $\begin{array}{l}\text { Andrews, C. R., \& Marotta, } \\
\text { S. A. (2005). }\end{array}$ & $\begin{array}{l}\text { Brewer, J. D., \& Sparkes, A. } \\
\text { C. (2011a). }\end{array}$ \\
\hline Setting & Early Years and School & $\begin{array}{l}\text { Primary and secondary schools in } \\
\text { Southeast London, England }\end{array}$ & $\begin{array}{l}\text { Recruitment from paediatric } \\
\text { offices, a hospital cancer } \\
\text { centre, a hospice, churches } \\
\text { and schools. }\end{array}$ & $\begin{array}{l}\text { Childhood bereavement } \\
\text { organisation in the UK. }\end{array}$ \\
\hline Participants & $\begin{array}{l}\text { A family (including two } \\
\text { bereaved siblings) }\end{array}$ & 13 school staff & $\begin{array}{l}6 \text { children and parents/main } \\
\text { caregiver }\end{array}$ & 13 young people. \\
\hline Details of bereavement & $\begin{array}{l}\text { Child (aged } 4 \text { ) died at home } \\
\text { in an accident. }\end{array}$ & Varied & $\begin{array}{l}\text { Family death within previous } \\
18 \text { months. }\end{array}$ & $\begin{array}{l}\text { Parentally bereaved young } \\
\text { people. }\end{array}$ \\
\hline Subject description & Case study & Interviews & Semi-structured interviews & Two-year ethnographic study \\
\hline Communication & $\begin{array}{l}\text { Eco-system (child, peers, } \\
\text { family and school). Talking } \\
\text { about deceased often } \\
\text { avoided. }\end{array}$ & $\begin{array}{l}\text { Work with child's immediate } \\
\text { family structure } \\
\text { Bereavement is often silenced if } \\
\text { behaviour doesn't change. }\end{array}$ & $\begin{array}{l}\text { Talking about (and to) the } \\
\text { deceased during rituals. }\end{array}$ & $\begin{array}{l}\text { Happiness is a choice } \\
\text { (communicating a positive } \\
\text { outlook). } \\
\text { 'Move past the awkwardness } \\
\text { some children feel in talking } \\
\text { about grief' }\end{array}$ \\
\hline Peer / Social Support & $\begin{array}{l}\text { Important when bad news is } \\
\text { disclosed. }\end{array}$ & $\begin{array}{l}\text { Social and personal side to school } \\
\text { Social withdrawal }\end{array}$ & - & $\begin{array}{l}\text { Connectedness to others who } \\
\text { suffer ('you feel like you're not } \\
\text { alone'). }\end{array}$ \\
\hline Expressing Emotion & $\begin{array}{l}\text { Happens informally and } \\
\text { spontaneously. Difficulty } \\
\text { within school framework to } \\
\text { provide for emotional } \\
\text { support. }\end{array}$ & $\begin{array}{l}\text { 'Low priority given to death and } \\
\text { bereavement within the school } \\
\text { curriculum.' } \\
\text { Space and time during school day } \\
\text { (time out). }\end{array}$ & $\begin{array}{l}\text { Making spiritual connections } \\
\text { with God or a Higher Person } \\
\text { to express emotion. }\end{array}$ & $\begin{array}{l}\text { Talking openly promotes } \\
\text { posttraumatic growth. }\end{array}$ \\
\hline
\end{tabular}




\begin{tabular}{|c|c|c|c|c|}
\hline $\begin{array}{l}\text { Role of Adult } \\
\text { (Relationships) }\end{array}$ & $\begin{array}{l}\text { No acknowledgement in } \\
\text { school. Alignment - Adults } \\
\text { perception is guided by } \\
\text { ability to read a child's } \\
\text { needs and wishes. Teacher } \\
\text { training (SMT responsible } \\
\text { for school infrastructure). }\end{array}$ & $\begin{array}{l}\text { Parents who support the school's } \\
\text { management of the child's } \\
\text { bereavement }\end{array}$ & $\begin{array}{l}\text { Routine maintained to fulfil a } \\
\text { containment role. } \\
\text { Adults who listen can reduce } \\
\text { anxiety. }\end{array}$ & Promote posttraumatic growth \\
\hline $\begin{array}{l}\text { Conceptualising } \\
\text { Bereavement (Meaning } \\
\text { Making) }\end{array}$ & $\begin{array}{l}\text { Death is final (making this } \\
\text { clear for young children). }\end{array}$ & $\begin{array}{l}\text { When child told class of father's } \\
\text { death, lack of experience and } \\
\text { understanding silenced the class } \\
\text { and the teacher decided to just } \\
\text { move on. } \\
\text { Learning grief terminology. }\end{array}$ & $\begin{array}{l}\text { Difficulty with making sense } \\
\text { of their experience. } \\
\text { Metaphors used to 'control } \\
\text { the uncontrollable'. }\end{array}$ & The ‘journey’ metaphor. \\
\hline Finding Comfort & $\begin{array}{l}\text { Play as a means to } \\
\text { understand what has } \\
\text { happened. }\end{array}$ & $\begin{array}{l}\text { Celebration of Life in schools for } \\
\text { students to attend }\end{array}$ & $\begin{array}{l}\text { Linking objects to connect } \\
\text { with decedent. } \\
\text { Play and toys make children } \\
\text { feel better. }\end{array}$ & 'Living life to the full' \\
\hline Stress and Trauma & $\begin{array}{l}\text { Explore links to disruptive } \\
\text { behaviour. }\end{array}$ & $\begin{array}{l}\text { Counselling (Reaching out to child } \\
\text { bereavement services) }\end{array}$ & - & $\begin{array}{l}\text { Bereavement provokes some } \\
\text { degree of trauma in all children } \\
\text { (shock and distress). }\end{array}$ \\
\hline Looking to the Future & - & - & - & Life paths \\
\hline
\end{tabular}

Note - Entries in quotation marks are original authors' own words; those not are paraphrasing. 


\section{Synthesis Translation: Continued}

\begin{tabular}{|c|c|c|c|c|}
\hline $\begin{array}{l}\text { Methods and concepts } \\
\text { (Reciprocal translation } \\
\text { and/or Refutational } \\
\text { synthesis) }\end{array}$ & $\begin{array}{l}\text { Brewer, J. D., \& Sparkes, A. } \\
\text { C. (2011b). }\end{array}$ & $\begin{array}{l}\text { Thompson, A. L., Miller, K. S., } \\
\text { Barrera, M., Davies, B., Foster, } \\
\text { T. L., Gilmer, M. J., ... , \& } \\
\text { Gerhardt, C. A. (2011). }\end{array}$ & $\begin{array}{l}\text { Keeley, M., \& Baldwin, P. } \\
\text { (2012). }\end{array}$ & $\begin{array}{l}\text { McClatchey, I. S., \& Wimmer, } \\
\text { J. S. (2012). }\end{array}$ \\
\hline Setting & $\begin{array}{l}\text { Childhood bereavement } \\
\text { organisation in the UK. }\end{array}$ & $\begin{array}{l}\text { Recruitment through children's } \\
\text { hospitals in the United States and } \\
\text { Canada. }\end{array}$ & $\begin{array}{l}\text { Three child bereavement } \\
\text { camps and one } \\
\text { counsellor's office. }\end{array}$ & Grief Camp \\
\hline Participants & 13 young people. & $\begin{array}{l}40 \text { families ( } 65 \text { parents, } 39 \\
\text { siblings) }\end{array}$ & Children & $\begin{array}{l}16 \text { parentally bereaved } \\
\text { children and their } 11 \text { surviving } \\
\text { parents }\end{array}$ \\
\hline Details of bereavement & $\begin{array}{l}\text { Parentally bereaved young } \\
\text { people. }\end{array}$ & Children who died from cancer & $\begin{array}{l}\text { Parental death resulting } \\
\text { from extended period of } \\
\text { illness (not sudden death) }\end{array}$ & $\begin{array}{l}\text { Parentally bereaved young } \\
\text { people. }\end{array}$ \\
\hline Subject description & Two-year ethnographic study & $\begin{array}{l}\text { Semi-structured Interviews (Part } \\
\text { of a longitudinal study) }\end{array}$ & $\begin{array}{l}\text { Retrospective semi- } \\
\text { structured interviews }\end{array}$ & Interviews \\
\hline Communication & - & $\begin{array}{l}\text { Talking about death in an open } \\
\text { and honest way provides an } \\
\text { outlet. }\end{array}$ & $\begin{array}{l}\text { Final conversations } \\
\text { (conducted during daily, } \\
\text { routine interactions): } \\
\text { comfort and security. }\end{array}$ & - \\
\hline Peer / Social Support & $\begin{array}{l}\text { 'You're not the only one who's } \\
\text { been through it.' } \\
\text { Friendships are to key } \\
\text { happiness. }\end{array}$ & As a means of embracing grief. & - & $\begin{array}{l}\text { Feeling different from other } \\
\text { children. } \\
\text { Friends sometimes want to } \\
\text { help but they don't know how } \\
\text { to. }\end{array}$ \\
\hline Expressing Emotion & $\begin{array}{l}\text { Sadness, anger, fear, } \\
\text { enjoyment - Non-judgemental } \\
\text { environment which facilitates, } \\
\text { but does not force, } \\
\text { expression of emotion. }\end{array}$ & $\begin{array}{l}\text { 'There should be no expectations } \\
\text { about how one should or should } \\
\text { not feel.' }\end{array}$ & - & $\begin{array}{l}\text { Overwhelming sadness and } \\
\text { anger - Children can feel they } \\
\text { have to hold it back. Feeling of } \\
\text { they 'can't put it anywhere'. }\end{array}$ \\
\hline
\end{tabular}




\begin{tabular}{|c|c|c|c|c|}
\hline $\begin{array}{l}\text { Role of Adult } \\
\text { (Relationships) }\end{array}$ & - & Continuing bonds & - & - \\
\hline $\begin{array}{l}\text { Conceptualising } \\
\text { Bereavement (Meaning } \\
\text { Making) }\end{array}$ & $\begin{array}{l}\text { Learning to live with } \\
\text { bereavement. } \\
\text { Metaphors }\end{array}$ & - & $\begin{array}{l}\text { Reflecting on time spent } \\
\text { with loved one before } \\
\text { death. }\end{array}$ & $\begin{array}{l}\text { Confused/anger when parent } \\
\text { dies by suicide is common ('It's } \\
\text { a selfish act and it's not fair to } \\
\text { the ones you leave behind.') - } \\
\text { Help to process is appropriate. }\end{array}$ \\
\hline Finding Comfort & $\begin{array}{l}\text { Physical activity. } \\
\text { "Visual, auditory, kinaesthetic } \\
\text { and a "secret sense".' } \\
\text { Recognise having fun is } \\
\text { important. } \\
\text { Ongoing relationship with the } \\
\text { dead parent. }\end{array}$ & $\begin{array}{l}\text { Recreational activities } \\
\text { Religion and faith is helpful in } \\
\text { coping (I.e. - God's plan). }\end{array}$ & $\begin{array}{l}\text { Rituals provide stability and } \\
\text { continuity. } \\
\text { Finding humour. }\end{array}$ & - \\
\hline Stress and Trauma & $\begin{array}{l}\text { Causing depression, panic } \\
\text { attacks and anxiety. } \\
\text { Techniques such as } \\
\text { relaxation and breathing. }\end{array}$ & - & - & $\begin{array}{l}\text { Internal turmoil can overtake } \\
\text { and impact on schooling } \\
\text { (attainment and behaviour) } \\
\text { and life. } \\
\text { Fears and worries related to } \\
\text { living family members. } \\
\text { Flashbacks can be traumatic. }\end{array}$ \\
\hline Looking to the Future & $\begin{array}{l}\text { Appreciation of life: 'She'll } \\
\text { always be through my life'. }\end{array}$ & $\begin{array}{l}\text { Importance of acceptance. } \\
\text { Looking forwards and continuing } \\
\text { to live one's life. }\end{array}$ & $\begin{array}{l}\text { Positivity around 'the family } \\
\text { journey after one of their } \\
\text { members died.' }\end{array}$ & $\begin{array}{l}\text { 'Move on with your life' } \\
\text { The wall metaphor. }\end{array}$ \\
\hline
\end{tabular}

Note - Entries in quotation marks are original authors' own words; those not are paraphrasing. 


\section{Synthesis Translation: Continued}

\begin{tabular}{|c|c|c|c|c|}
\hline $\begin{array}{l}\text { Methods and concepts } \\
\text { (Reciprocal translation } \\
\text { and/or Refutational } \\
\text { synthesis) }\end{array}$ & $\begin{array}{l}\text { Bugge, K. E., Darbyshire, } \\
\text { P., Røkholt, E. G., } \\
\text { Haugstvedt, K. T. S., \& } \\
\text { Helseth, S. (2014). }\end{array}$ & $\begin{array}{l}\text { Lane, N., Rowland, A., \& } \\
\text { Beinart, H. (2014). }\end{array}$ & $\begin{array}{l}\text { Dyregrov, K., Endsjø, M., } \\
\text { Idsøe, T., \& Dyregrov, A. } \\
\text { (2015). }\end{array}$ & $\begin{array}{l}\text { Nilsson, D., \& Ängarne- } \\
\text { Lindberg, T. (2016). }\end{array}$ \\
\hline Setting & $\begin{array}{l}\text { Norwegian Bereavement } \\
\text { Support Program }\end{array}$ & Secondary School & Schools in Norway & Childhood Trauma Team \\
\hline Participants & 8 parents & 12 teachers & $\begin{array}{l}17 \text { teachers and } 5 \text { head } \\
\text { teachers from primary and } \\
\text { secondary schools }\end{array}$ & $\begin{array}{l}14 \text { parentally bereaved } \\
\text { children and their } 15 \text { surviving } \\
\text { parents }\end{array}$ \\
\hline Details of bereavement & $\begin{array}{l}\text { Sibling deaths and parentally } \\
\text { bereaved children. }\end{array}$ & $\begin{array}{l}\text { Teachers with experience of } \\
\text { working with parentally } \\
\text { bereaved young people in the } \\
\text { last } 5 \text { years. }\end{array}$ & Varied & $\begin{array}{l}\text { Parentally bereaved young } \\
\text { people. }\end{array}$ \\
\hline Subject description & Interviews & Semi-structured interviews & Focus group interviews & Interviews \\
\hline Communication & $\begin{array}{l}\text { Children liked to talk about } \\
\text { deceased (especially in } \\
\text { everyday conversations - } \\
\text { 'keeping their dead siblings } \\
\text { alive'). }\end{array}$ & $\begin{array}{l}\text { Openness to speak about death } \\
\text { and bereavement (teachers can } \\
\text { lack confidence). } \\
\text { Communication with family is } \\
\text { important... 'even if it's } \\
\text { awkward.' }\end{array}$ & $\begin{array}{l}\text { Some schools have a } \\
\text { response action plan } \\
\text { Parent/carer and school } \\
\text { communicate to agree } \\
\text { appropriate adaptations }\end{array}$ & $\begin{array}{l}\text { Using conversations and } \\
\text { concrete/practical activities to } \\
\text { ensure information is good to } \\
\text { receive (clarity and structure). }\end{array}$ \\
\hline Peer / Social Support & - & $\begin{array}{l}\text { Addressing death and } \\
\text { separation anxieties which the } \\
\text { friends of the bereaved young } \\
\text { person are experiencing. }\end{array}$ & - & - \\
\hline Expressing Emotion & $\begin{array}{l}\text { Can be erratic, confusing and } \\
\text { painful to witness. }\end{array}$ & $\begin{array}{l}\text { Informal emotional support can } \\
\text { be given by teachers/adults. } \\
\text { A feeling of self-acceptance of } \\
\text { your emotions. }\end{array}$ & $\begin{array}{l}\text { Psychological space for grief } \\
\text { ("left alone") }\end{array}$ & $\begin{array}{l}\text { Using conversations and } \\
\text { concrete/practical activities to } \\
\text { attend to emotional chaos } \\
\text { (inner order). }\end{array}$ \\
\hline
\end{tabular}




\begin{tabular}{|c|c|c|c|c|}
\hline $\begin{array}{l}\text { Role of Adult } \\
\text { (Relationships) }\end{array}$ & $\begin{array}{l}\text { Provide security and } \\
\text { predictability. }\end{array}$ & $\begin{array}{l}\text { Ensuring and maintaining } \\
\text { normality whilst being adaptive. } \\
\text { Feeling emotionally involved, } \\
\text { including sharing own personal } \\
\text { experience. } \\
\text { Teachers feeling '...helpless, } \\
\text { useless and ignorant of the right } \\
\text { thing to say'. }\end{array}$ & $\begin{array}{l}\text { Targeted measures in schools } \\
\text { Being available and present. } \\
\text { Aware of long-term } \\
\text { perspectives on grief. }\end{array}$ & - \\
\hline $\begin{array}{l}\text { Conceptualising } \\
\text { Bereavement (Meaning } \\
\text { Making) }\end{array}$ & $\begin{array}{l}\text { What is means to be dead } \\
\text { and where dead parent or } \\
\text { sibling had gone. } \\
\text { Some children are too young } \\
\text { to remember. }\end{array}$ & - & - & $\begin{array}{l}\text { Able to ask questions without } \\
\text { worrying about making others } \\
\text { sad or angry (talking to } \\
\text { someone who isn't } \\
\text { experiencing the grief directly). }\end{array}$ \\
\hline Finding Comfort & $\begin{array}{l}\text { Children liked to see pictures } \\
\text { and videos of the deceased. } \\
\text { Use of metaphor - 'heaven'. }\end{array}$ & - & - & $\begin{array}{l}\text { Feeling confident and secure } \\
\text { in an environment. }\end{array}$ \\
\hline Stress and Trauma & $\begin{array}{l}\text { Fears and worries related to } \\
\text { illnesses and other potential } \\
\text { death. }\end{array}$ & - & - & - \\
\hline Looking to the Future & $\begin{array}{l}\text { Sense of belonging. 'New } \\
\text { life'. }\end{array}$ & $\begin{array}{l}\text { Teachers express ongoing } \\
\text { impact of bereavement on } \\
\text { young people throughout their } \\
\text { schooling and life. }\end{array}$ & - & - \\
\hline
\end{tabular}

Note - Entries in quotation marks are original authors' own words; those not are paraphrasing. 


\section{Synthesis Translation: Continued}

\begin{tabular}{|c|c|c|c|}
\hline $\begin{array}{l}\text { Methods and concepts } \\
\text { (Reciprocal translation } \\
\text { and/or Refutational } \\
\text { synthesis) }\end{array}$ & $\begin{array}{l}\text { Søfting, G. H., Dyregrov, A., \& } \\
\text { Dyregrov, K. (2016). }\end{array}$ & $\begin{array}{l}\text { Brooten, D., \& Youngblut, J. M. } \\
\text { (2017). }\end{array}$ & $\begin{array}{l}\text { Richardson, R. A., Ferguson, P. } \\
\text { A., \& Maxymiv, S. (2017). }\end{array}$ \\
\hline Setting & $\begin{array}{l}\text { Recruitment through } \\
\text { advertisement and Center for } \\
\text { Crisis Psychology }\end{array}$ & $\begin{array}{l}\text { Recruitment from four South } \\
\text { Florida hospitals and Florida } \\
\text { obituaries. }\end{array}$ & Bereavement camps \\
\hline Participants & 11 children (Norwegian) & $\begin{array}{l}\text { Responses from } 6 \text {-year-old to } 12- \\
\text { year-old children. }\end{array}$ & Children \\
\hline Details of bereavement & $\begin{array}{l}\text { Experienced loss of a sibling or } \\
\text { parent }\end{array}$ & Sibling death. & Death of a loved one \\
\hline Subject description & Interviews & Semi-structured interviews & Observations \\
\hline Communication & $\begin{array}{l}\text { Having someone to talk to. } \\
\text { Talking to the deceased. }\end{array}$ & Talking to deceased sibling. & Naming aloud the deceased \\
\hline Peer / Social Support & - & - & $\begin{array}{l}\text { Healing circles } \\
\text { Feeling of belonging and 'fitting in' }\end{array}$ \\
\hline Expressing Emotion & $\begin{array}{l}\text { Provide sufficient emotional } \\
\text { space. }\end{array}$ & $\begin{array}{l}\text { Thinking about their deceased } \\
\text { sibling, crying and feeling sad. }\end{array}$ & $\begin{array}{l}\text { Encourage but do not go beyond } \\
\text { level of the grieving child's own } \\
\text { comfort. } \\
\text { It's okay to be scared, sad and to } \\
\text { cry. }\end{array}$ \\
\hline $\begin{array}{l}\text { Role of Adult } \\
\text { (Relationships) }\end{array}$ & $\begin{array}{l}\text { Explain rituals to children } \\
\text { before they take place. } \\
\text { Children grieve alongside } \\
\text { adults (They are never too } \\
\text { young - 'I'm also part of the }\end{array}$ & $\begin{array}{l}\text { Spending more time as a family. } \\
\text { Talking with children as a coping } \\
\text { strategy. }\end{array}$ & $\begin{array}{l}\text { Encourage and positive feedback } \\
\text { when working through grief. }\end{array}$ \\
\hline
\end{tabular}




\begin{tabular}{|l|l|l|l|}
\hline & family'). & & \\
\hline $\begin{array}{l}\text { Conceptualising } \\
\text { Bereavement (Meaning } \\
\text { Making) }\end{array}$ & $\begin{array}{l}\text { Involve children in rituals. } \\
\text { Empowerment through } \\
\text { involvement. }\end{array}$ & $\begin{array}{l}\text { 'I wish...' - Thinking about how } \\
\text { death could have been stopped. }\end{array}$ & $\begin{array}{l}\text { Provide protected psychological } \\
\text { space } \\
\text { Learning grief terminology }\end{array}$ \\
\hline Finding Comfort & $\begin{array}{l}\text { Time and place for reflection } \\
\text { and memories (I.e. - visiting the } \\
\text { grave). }\end{array}$ & $\begin{array}{l}\text { Involvement in funeral and } \\
\text { celebrations of life. } \\
\text { Praying. } \\
\text { New activities (sports, drawing } \\
\text { etc). }\end{array}$ & Not alone with their grief. \\
\hline Stress and Trauma & - & $\begin{array}{l}\text { Experiencing a similar situation all } \\
\text { over again. } \\
\text { Fears and worries related to living } \\
\text { family members. }\end{array}$ & - \\
\hline Looking to the Future & - & $\begin{array}{l}\text { Positive changes after de-track - } \\
\text { valuing life. }\end{array}$ & - \\
\hline
\end{tabular}

Note - Entries in quotation marks are original authors' own words; those not are paraphrasing. 
Table 1 Ratings of the appropriateness of included studies (adapted from Liabo, Gray and Mulcahy, 2013).

\begin{tabular}{|c|c|c|c|c|c|}
\hline Study & $\begin{array}{l}\text { What is the } \\
\text { relevance of the } \\
\text { topic focus of the } \\
\text { study to the } \\
\text { review question? }\end{array}$ & $\begin{array}{l}\text { Is the data } \\
\text { collection } \\
\text { method } \\
\text { appropriate } \\
\text { to the } \\
\text { research } \\
\text { questions? }\end{array}$ & $\begin{array}{l}\text { Are the } \\
\text { results of the } \\
\text { study sound? }\end{array}$ & $\begin{array}{l}\text { Is this study } \\
\text { type } \\
\text { appropriate } \\
\text { for } \\
\text { answering } \\
\text { the review } \\
\text { question? }\end{array}$ & $\begin{array}{l}\text { Overall } \\
\text { weight }\end{array}$ \\
\hline $\begin{array}{l}\text { Andrews, C. } \\
\text { R., \& Marotta, } \\
\text { S. A. (2005). }\end{array}$ & Medium & High & High & Medium & Medium \\
\hline $\begin{array}{l}\text { Brewer, J. D., } \\
\text { \& Sparkes, A. } \\
\text { C. (2011a). }\end{array}$ & Medium & High & High & Medium & High \\
\hline $\begin{array}{l}\text { Brewer, J. D., } \\
\text { \& Sparkes, A. } \\
\text { C. (2011b). }\end{array}$ & High & High & High & High & High \\
\hline $\begin{array}{l}\text { Brooten, D., \& } \\
\text { Youngblut, J. } \\
\text { M. (2017). }\end{array}$ & High & High & High & High & High \\
\hline $\begin{array}{l}\text { Bugge, K. E., } \\
\text { Darbyshire, P., } \\
\text { Røkholt, E. G., } \\
\text { Haugstvedt, K. } \\
\text { T. S., \& } \\
\text { Helseth, S. } \\
\text { (2014). }\end{array}$ & High & Medium & Medium & High & High \\
\hline $\begin{array}{l}\text { Dyregrov, K., } \\
\text { Endsjø, M., } \\
\text { Idsøe, T., \& } \\
\text { Dyregrov, A. } \\
\text { (2015). }\end{array}$ & High & High & Medium & High & High \\
\hline $\begin{array}{l}\text { Keeley, M., \& } \\
\text { Baldwin, P. } \\
\text { (2012). }\end{array}$ & Medium & High & High & Medium & Medium \\
\hline $\begin{array}{l}\text { Lane, N., } \\
\text { Rowland, A., \& } \\
\text { Beinart, H. } \\
\text { (2014). }\end{array}$ & Medium & Medium & High & High & High \\
\hline $\begin{array}{l}\text { Lowton, K., \& } \\
\text { Higginson, I. J. } \\
\text { (2003). }\end{array}$ & High & High & Medium & High & High \\
\hline $\begin{array}{l}\text { McClatchey, I. } \\
\text { S., \& Wimmer, } \\
\text { J. S. (2012). }\end{array}$ & High & High & High & High & High \\
\hline $\begin{array}{l}\text { Nilsson, D., \& } \\
\text { Ängarne- }\end{array}$ & High & High & Medium & High & High \\
\hline
\end{tabular}


Lindberg, T.

(2016).

Reid, J. (2002). Medium

Richardson, R. Medium

A., Ferguson,

P. A., \&

Maxymiv, S.

(2017).

Søfting, G. H., Medium

Dyregrov, A., \&

Dyregrov, $\mathrm{K}$.

(2016).

Thompson, A.

L., Miller, K. S.,

Barrera, M.,

Davies, B.,

Foster, T. L.,

Gilmer, M. J.,

$\ldots$, \&

Gerhardt, C. A.

(2011).

\begin{tabular}{|l|l|l|l|l|}
\hline Medium & High & Medium & High & High \\
\hline Medium & High & High & Medium & Medium \\
\hline High & Medium & High & High & High \\
\hline
\end{tabular}


Table 2 Themes present in the included studies

Communication Andrews, C. R., \& Marotta, S. A. (2005).

Brewer, J. D., \& Sparkes, A. C. (2011a).

Brooten, D., \& Youngblut, J. M. (2017).

Bugge, K. E., Darbyshire, P., Røkholt, E. G., Haugstvedt, K. T. S., \& Helseth, S. (2014).

Dyregrov, K., Endsjø, M., Idsøe, T., \& Dyregrov, A. (2015).

Keeley, M., \& Baldwin, P. (2012).

Lane, N., Rowland, A., \& Beinart, H. (2014).

Lowton, K., \& Higginson, I. J. (2003).

Nilsson, D., \& Ängarne-Lindberg, T. (2016).

Reid, J. (2002).

Richardson, R. A., Ferguson, P. A., \& Maxymiv, S. (2017).

Søfting, G. H., Dyregrov, A., \& Dyregrov, K. (2016).

Thompson, A. L., Miller, K. S., Barrera, M., Davies, B., Foster,

T. L., Gilmer, M. J., ... , \& Gerhardt, C. A. (2011).

Peer/Social Support

Expressing Emotion

Brewer, J. D., \& Sparkes, A. C. (2011a).

Brewer, J. D., \& Sparkes, A. C. (2011b).

Lane, N., Rowland, A., \& Beinart, H. (2014).

Lowton, K., \& Higginson, I. J. (2003).

McClatchey, I. S., \& Wimmer, J. S. (2012).

Reid, J. (2002).

Richardson, R. A., Ferguson, P. A., \& Maxymiv, S. (2017).

Thompson, A. L., Miller, K. S., Barrera, M., Davies, B., Foster,

T. L., Gilmer, M. J., ... , \& Gerhardt, C. A. (2011).

Andrews, C. R., \& Marotta, S. A. (2005).

Brewer, J. D., \& Sparkes, A. C. (2011a).

Brewer, J. D., \& Sparkes, A. C. (2011b).

Brooten, D., \& Youngblut, J. M. (2017).

Bugge, K. E., Darbyshire, P., Røkholt, E. G., Haugstvedt, K.

T. S., \& Helseth, S. (2014).

Dyregrov, K., Endsjø, M., Idsøe, T., \& Dyregrov, A. (2015).

Lane, N., Rowland, A., \& Beinart, H. (2014).

Lowton, K., \& Higginson, I. J. (2003).

McClatchey, I. S., \& Wimmer, J. S. (2012).

Nilsson, D., \& Ängarne-Lindberg, T. (2016).

Reid, J. (2002).

Richardson, R. A., Ferguson, P. A., \& Maxymiv, S. (2017).

Søfting, G. H., Dyregrov, A., \& Dyregrov, K. (2016).

Thompson, A. L., Miller, K. S., Barrera, M., Davies, B., Foster,

T. L., Gilmer, M. J., .. , \& Gerhardt, C. A. (2011).

Role of Adult (Including relationships)
Andrews, C. R., \& Marotta, S. A. (2005).

Brewer, J. D., \& Sparkes, A. C. (2011a).

Brooten, D., \& Youngblut, J. M. (2017).

Bugge, K. E., Darbyshire, P., Røkholt, E. G., Haugstvedt, K.

T. S., \& Helseth, S. (2014).

Dyregrov, K., Endsjø, M., Idsøe, T., \& Dyregrov, A. (2015).

Lane, N., Rowland, A., \& Beinart, H. (2014).

Lowton, K., \& Higginson, I. J. (2003).

Reid, J. (2002).

Richardson, R. A., Ferguson, P. A., \& Maxymiv, S. (2017).

Søfting, G. H., Dyregrov, A., \& Dyregrov, K. (2016).

Thompson, A. L., Miller, K. S., Barrera, M., Davies, B., Foster, T. L., Gilmer, M. J., ... \& \& Gerhardt, C. A. (2011).

Conceptualising Bereavement (Meaning Making)
Andrews, C. R., \& Marotta, S. A. (2005).

Brewer, J. D., \& Sparkes, A. C. (2011a).

Brewer, J. D., \& Sparkes, A. C. (2011b).

Brooten, D., \& Youngblut, J. M. (2017).

Bugge, K. E., Darbyshire, P., Røkholt, E. G., Haugstvedt, K. T. S., \& Helseth, S. (2014). 


\begin{tabular}{ll}
\hline & Keeley, M., \& Baldwin, P. (2012). \\
Lowton, K., \& Higginson, I. J. (2003). \\
McClatchey, I. S., \& Wimmer, J. S. (2012). \\
Nilsson, D., \& Angarne-Lindberg, T. (2016). \\
Reid, J. (2002). \\
Richardson, R. A., Ferguson, P. A., \& Maxymiv, S. (2017). \\
Søfting, G. H., Dyregrov, A., \& Dyregrov, K. (2016). \\
Andrews, C. R., \& Marotta, S. A. (2005). \\
Brewer, J. D., \& Sparkes, A. C. (2011a). \\
Brewer, J. D., \& Sparkes, A. C. (2011b). \\
Brooten, D., \& Youngblut, J. M. (2017). \\
Bugge, K. E., Darbyshire, P., Røkholt, E. G., Haugstvedt, K. \\
T. S., \& Helseth, S. (2014). \\
Keeley, M., \& Baldwin, P. (2012). \\
Lowton, K., \& Higginson, I. J. (2003). \\
Nilsson, D., \& Ängarne-Lindberg, T. (2016). \\
Reid, J. (2002). \\
Richardson, R. A., Ferguson, P. A., \& Maxymiv, S. (2017). \\
Søfting, G. H., Dyregrov, A., \& Dyregrov, K. (2016). \\
Thompson, A. L., Miller, K. S., Barrera, M., Davies, B., Foster, \\
T. L., Gilmer, M. J., .., \& Gerhardt, C. A. (2011). \\
Brewer, J. D., \& Sparkes, A. C. (2011a). \\
Brewer, J. D., \& Sparkes, A. C. (2011b). \\
Brooten, D., \& Youngblut, J. M. (2017). \\
Bugge, K. E., Darbyshire, P., Røkholt, E. G., Haugstvedt, K. \\
T. S., \& Helseth, S. (2014). \\
Lowton, K., \& Higginson, I. J. (2003). \\
McClatchey, I. S., \& Wimmer, J. S. (2012). \\
Reid, J. (2002). \\
\hline Brewer, J. D., \& Sparkes, A. C. (2011a). \\
Brewer, J. D., \& Sparkes, A. C. (2011b). \\
Brooten, D., \& Youngblut, J. M. (2017). \\
Bugge, K. E., Darbyshire, P., Røkholt, E. G., Haugstvedt, K. \\
T. S., \& Helseth, S. (2014). \\
Keeley, M., \& Baldwin, P. (2012). \\
Lane, N., Rowland, A., \& Beinart, H. (2014). \\
McClatchey, I. S., \& Wimmer, J. S. (2012). \\
Thompson, A. L., Miller, K. S., Barrera, M., Davies, B., Foster, \\
T. L., Gilmer, M. J., .., \& Gerhardt, C. A. (2011). \\
\end{tabular}


Table 3 Description of common approaches

\begin{tabular}{l|l} 
Communication & $\begin{array}{l}\text { Having conversations about death and dying can show children } \\
\text { that adults care about their lived experience. }\end{array}$ \\
\hline Peer/Social Support & $\begin{array}{l}\text { The role of peers is crucial in supporting children and young } \\
\text { people when they experience the death of a loved one. }\end{array}$ \\
\hline Expressing Emotion & $\begin{array}{l}\text { Children's emotions will be unpredictable and sporadic. This will } \\
\text { impact on them physically, socially and emotionally. Encouraging } \\
\text { children to recognise, channel and explore their emotions can be } \\
\text { healing. }\end{array}$ \\
\hline $\begin{array}{l}\text { Role of Adult } \\
\text { Including } \\
\text { relationships) }\end{array}$ & $\begin{array}{l}\text { Adults can provide security and structure at a time where the child } \\
\text { may feel lost and alone. Be prepared to listen, over and over } \\
\text { again. }\end{array}$ \\
\hline $\begin{array}{l}\text { Conceptualising } \\
\text { (Meanement }\end{array}$ & $\begin{array}{l}\text { Expose children to grief processes and what kind of experiences } \\
\text { they may live through. Sharing stories and talking about what } \\
\text { death means can be reassuring for the child. }\end{array}$ \\
\hline Finding Comfort & $\begin{array}{l}\text { Spending time focusing on the death can help children feel a } \\
\text { connection to the deceased. Yet, this can also be painful. } \\
\text { Encourage children to find comfort by 'switching off' and looking } \\
\text { after themselves. }\end{array}$ \\
\hline Stress and Trauma & $\begin{array}{l}\text { Death of a loved one can trigger serious health problems. Every } \\
\text { child will react differently and this should be monitored over short } \\
\text { and longer terms, with a holistic view of the child in mind. }\end{array}$ \\
\hline Looking to the & $\begin{array}{l}\text { Children will adapt to a new life: living with the death. Take time to } \\
\text { explore the child's desires and needs for the future. }\end{array}$ \\
\hline Future
\end{tabular}



$(n=749)$

$$
(n=16)
$$

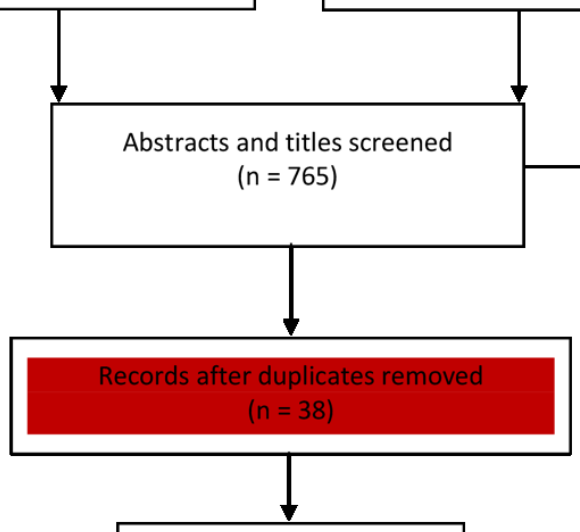

Full-text articles assessed for eligibility $(\mathrm{n}=38)$

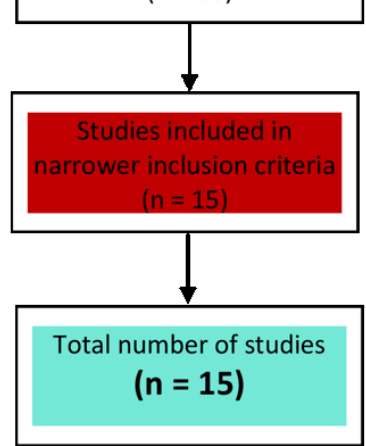

Records excluded

$(n=727)$

Reasons for Exclusion

Not topic related -635

Not qualitative -38

Not in English - 16

Duplicates - 38

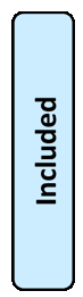

Records excluded $(n=23)$

Reasons for Exclusion Not linked to learning and approaches for school aged children - 10 Not qualitative - 13

(Fig. 1 - Flow diagram of search outcomes) 
Qualitative Enquiry Model

Using elements of systematic review and meta-ethnography protocol

Planning the Review

Develop and validate the review protocol

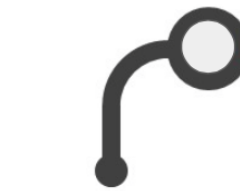

Review Question Resulting from Retrospective Autoethnography

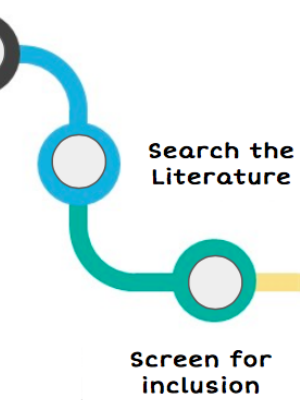

Synthesising Translation Using components: Reciprocal translation; Refutational synthesis; Line of argument

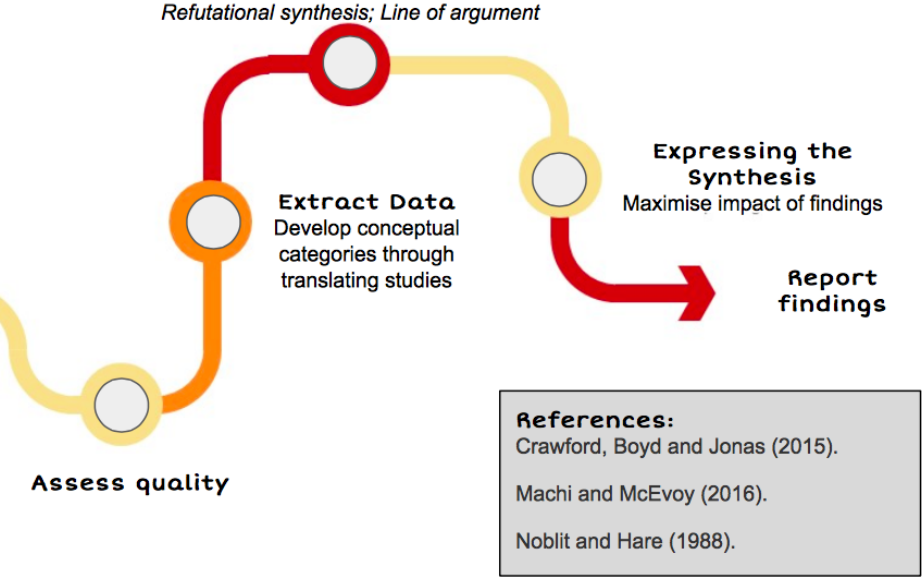

(Fig. 2 - Qualitative enquiry model developed to be used as review protocol) 


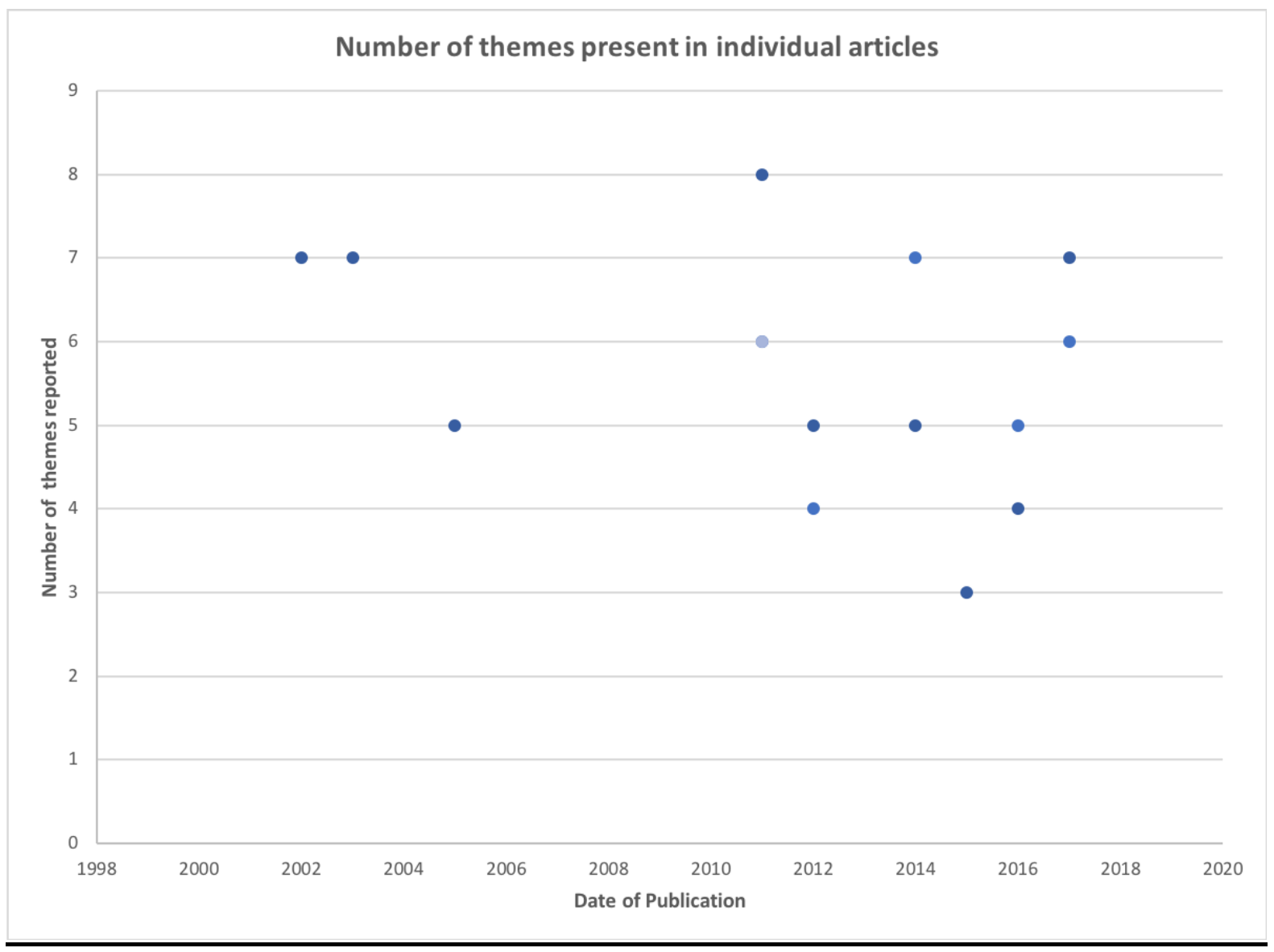

(Fig. 3 - Chronological comparison of number of themes present in individual articles) 